\title{
PHRASAL VERBS IN GENERAL ENGLISH AND TRAFFIC ENGINEERING AND THEIR SERBIAN EQUIVALENTS ${ }^{1}$
}

\begin{abstract}
This paper examines the use of phrasal verbs in general English and in some traffic engineering contexts in order to reveal their meanings, provide their translation equivalents in Serbian, and establish their frequency of occurrence in spoken English and written specific discourse. The corpus comprises 46 phrasal verbs and examples are taken from authentic sources. Although phrasal verbs are often regarded as colloquial, informal and slangy (cf. Palmer 1988), the examples in this paper demonstrate that they can be neutral and formal as well. The findings suggest that phrasal verbs can be found in specialised traffic engineering texts of different genres, and that polysemy and idiomaticity are the main characteristics of phrasal verbs.
\end{abstract}

Key words: phrasal verbs, general English and traffic engineering English, Serbian equivalents, spoken language and written discourse, semantic analysis

\section{Introduction}

English is the most widely used international language today. Billions of people need the ability to communicate in a successful way, in both general/primary and specialised/secondary contexts. Idiomaticity is an important aspect of this ability.

Phraseological units are determined by non-compositionality or idiomaticity. The meaning of an idiomatic phraseological unit cannot be deduced from the sum of the individual meanings of its parts, but rather it is deduced from the phraseological unit as a whole, which argues for phrasal verbs to be produced, stored and learnt as complete units placed in the lexicon (cf. Jackendoff 2002: 73).

Phrasal verbs are categorised differently in the relevant literature. Alexander (1978: 180), for example, lists phrasal verbs in his taxonomy of fixed expressions under

\footnotetext{
*Faculty of Transport and Traffic Engineering, University of Belgrade, Vojvode Stepe 305, 11000 Belgrade, Serbia; e-mail: g.dimkovic@sf.bg.ac.rs

1 This paper is based on a study conducted within the project Description and Standardisation of Contemporary Serbian Language, Grant No. 178021, funded by the Ministry of Education, Science and Technological Development of the Republic of Serbia, and realised at the Serbian Academy of Sciences and Arts.
} 
'idioms'. Lipka (1972: 74) maintains that phrasal verbs are considered phraseological units by analogy with collocations, since "a simplex verb collocates with a particle", as in to go away ('otići', 'prestati'), to pull over ('zaustaviti', 'stati'), and to watch out ('paziti'), for instance. Phrasal verbs can also contain three parts: Verb + Particle + Preposition. These constituents make up a phraseological unit, having one meaning (e. g. to put up with $\rightarrow$ 'podnositi', to run out of $\rightarrow$ 'nestati', to get through to sth $\rightarrow$ 'uspostaviti vezu sa nekim, s nečim', etc.). Mitchell (1958: 103) and Howarth (1998: 28) classify phrasal verbs as 'grammatical collocations', since they consist of one open-class item (the verb) and one closed-class item (the particle), and are therefore placed at the interface of grammar and lexis. Such units are fixed to at least some degree, either syntactically or lexically, and cannot be changed randomly. To illustrate grammatical collocations, Cowie (1994: 3169) provides the following examples: perform an experiment and conduct an experiment are both possible, whereas *perform a survey is not acceptable for no apparent semantic reason, in contrast to conduct a survey. Transitive phrasal verbs co-occur with specific context words or collocates in a similar way, e.g. carry out work/tasks/studies/research, but not carry out revenge/a race. If grammar and semantics are the criteria according to which phrasal verbs are classified, phrasal verbs can be placed at the interface of grammar and lexis, and can be regarded as grammatical collocations. Contrary to this, phrasal verbs can be categorised as multi-word units placed in the lexicon, when semantics is taken as the only criterion for their categorisation.

In this paper, phrasal verbs are considered 'idiomatic phraseological units', as our focus in the analysis is on the phrasal verbs' semantics. Examples given in Section 3. illustrate that the individual items of an idiomatic phraseological unit do not make up its meaning, but its meaning is deduced from the unit as a whole.

\section{Aims and scope of the present study}

The present study is a continuation of the research carried out in 2013 (see Dimković-Telebaković 2013). The corpus has been subjected to a semantic analysis of phrasal-verb usage in general English and in some fields of traffic engineering in order to reveal their meanings, to find their Serbian equivalents, and to determine how frequently they emerge in spoken discourse and written specialised English under discussion. The corpus comprises 46 phrasal verbs extracted from relevant literature and a dictionary (Macmillan Phrasal Verbs Plus 2005). Examples are taken from authentic sources. 


\section{Analysis and results}

In Section 3.1, we look at 8 polysemous phrasal verbs. Section 3.2 discusses 12 phrasal units as used in informal English, Section 3.3 deals with 3 phrasal verbs as reflected in formal traffic engineering settings, and Section 3.4 analyses 3 neutral phrasal-verb uses. In Section 3.5, three dialogues, containing 5 phraseological units, and five traffic engineering texts, comprising 15 phrasal verbs, are examined in terms of their meanings and frequency of occurrence. It is important to point out here that only some meanings of the phraseological units considered are covered in this paper, since the semantics of phrasal verbs is very rich.

\subsection{Phrasal verbs and polysemy}

Polysemy is one of the peculiarities of phrasal verbs, besides noncompositionality or idiomaticity. If a phrasal verb expresses different meanings, it is said to be polysemous. Some examples in this section show that one phrasal verb can convey different meanings in general English and specific language, and other examples illustrate that two different phrasal verbs can have the same meaning when used in the same context.

The following examples show that the meaning of the phrasal verb to roll out in general English is 'to unroll', i.e. 'odmotati', or 'raširiti' in Serbian.

(1a) She rolled out the document on the table.

(taken from Macmillan Phrasal Verbs Plus 2005: 365)

'Raširila je dokument na stolu.'

Examples in (1b) illustrate that the meaning of the phrasal verb to roll out can be 'to introduce', and 'uvesti' in Serbian, if used in specialised language.

(1b) Once passed, the new regulations will be rolled out gradually over the coming years.

(taken from Dimković-Telebaković 2018: 83)

'Jednom doneti, novi propisi biće postepeno uvođeni tokom narednih godina.'

Examples in (2a) show that the phrasal verb to take off can for instance convey the meaning of 'copy sb's behaviour for fun' in general English. Its equivalent in Serbian is 'podražavati'. If this phrasal verb is used in air traffic, as illustrated by example (2b), it expresses the meaning of 'to leave the ground and start flying'. Its Serbian equivalent is 'poletati'. 
(2a) Beth can take off Jane brilliantly. 'Bet može odlično da podražava Džejn.'

(2b) The plane is taking off now.

'Avion sada poleće.'

The phrasal verb to get around $s b$ can have the meaning of 'to persuade someone to do something, especially by being nice to them', as used in everyday English. In Serbian, its equivalent is 'obrlatiti', which is demonstrated by (3a) below.

(3a) She really knows how to get around her dad.

(taken from Macmillan Phrasal Verbs Plus 2005: 172)

'Ona stvarno zna kako da obrlati tatu.'

In (3b), the phrasal verb to get around has the meaning of 'to travel to different places without much difficulty', and its equivalent in Serbian is 'obilaziti'.

(3b) The easiest and quickest way to get around central London is by the Underground.

(taken from Dimković-Telebaković 2015b: 44) 'Podzemnom železnicom može se najlakše i najbrže obići centralni London.'

In colloquial English, the phrasal verb to back up can have the meaning of 'to give support to someone by saying or showing that you agree with them', and its Serbian equivalent is 'podržati', as illustrated in (4a).

(4a) If I ask for more money will you back me up?

(taken from Macmillan Phrasal Verbs Plus 2005: 15)

'Ako te zamolim za još novca, da li ćeš me podržati?

Example (4b) shows that the phrasal verb to back up, when referring to traffic, has the meaning of 'stop moving and become blocked', and its Serbian equivalent is 'nagomilavati se'.

(4b) Traffic is backing up on all out-of-town routes.

(taken from Macmillan Phrasal Verbs Plus 2005: 18)

'Vozila u saobraćaju se nagomilavaju na svim putevima iz grada.'

The phrasal verb to back up can also convey other meanings. In (4c), it has the meaning of 'to make a car go backwards', that is, 'to reverse', whereas its meaning in (4d) is 'to make a copy of information on your computer', i. e. 'to copy'. Their Serbian equivalents are as follows: 'pomeriti auto unazad', and 'napraviti kopiju dokumenta' (or, much more commonly, 'bekapovati'), respectively. 
(4c) Could you back your car up a bit?

'Da li možete malo da pomerite auto unazad?'

(4d) I forgot to back it up and now it's lost forever!

'Zaboravio sam da napravim kopiju dokumenta i sada je zauvek izgubljen.'

The phrasal verb to drop off as used in (5a) has the meaning of 'to start to sleep', 'to fall asleep', and it is translated into Serbian as 'zaspati'. Maxwell (2005) illustrates a pure neologism to gronk out, which has the same meaning as to drop off: e. g. Manin gronks out and begins to snore lightly $\rightarrow$ 'Manin zaspi i lako zahrče.' It is worth pointing out that this slang item was not a long-lived lexeme. It is rarely used today.

(5a) I was sitting in the armchair and I dropped off.

'Sedela sam u fotelji i zaspala.'

If this phrasal unit is used in another context, it can have the meaning of 'to take someone to a place in a car', that is, 'odvesti kolima', 'odbaciti kolima' in Serbian, as shown by $(5 b)$.

(5b) I can drop you off at the station.

'Mogu da te odvezem na stanicu.'

Sentences in (6) demonstrate the phrasal verb to go off which has the meaning of 'prestati da radi' or 'isključiti se' or 'blokirati se'. Another phrasal verb having the same meaning of 'to stop working when referring to a machine or electrical device' is to gronk out, which is illustrated by My terminal just gronked out! (see Maxwell 2005). The translation of this sentence into Serbian is 'Moj računar je tek tako/odjednom prestao da radi!'

(6) My computer keeps going off for no apparent reason.

'Moj računar se stalno isključuje/blokira bez jasnog razloga.'

The phrasal verb to burst out, being a transitive phrasal verb, either collocates with laughing or with crying, and results in two meanings - 'prsnuti u smeh' or 'briznuti u plač', respectively, as shown in (7) and (8).

(7) She burst out laughing, thinking I was joking.

'Prsla je u smeh, misleći da se šalim.'

(8) He suddenly burst out crying.

'Iznenada je briznuo u plač.'

Analysing phrasal verbs in academic writing, Lakoff (1973) provides us with examples which illustrate how the same phrasal verbs convey various meanings if they collocate with different words. 


\subsection{Phrasal verbs in informal English}

Examples in this section of the paper are taken from Macmillan Phrasal Verbs Plus (2005), McCarthy and O'Dell (2007), and Dimković-Telebaković (2018). They illustrate English phrasal verbs as used in informal English, and are followed by their Serbian translations.

(9) I asked them: "Can you keep the noise down a bit?"

'Pitao sam ih: „Da li možete malo da smanjite tu buku?",

(10) They have informed us that they have more or less settled in to their new flat. 'Obavestili su nas da su se manje više sredili u svom novom stanu.'

(11) Hurry up! We'll miss the 7 o'clock bus. 'Požuri! Zakasnićemo na autobus u 7.'

Example (12) contains the phrasal verb to call up, which has the meaning of 'to make you remember something', or 'to evoke'. This phrasal unit collocates with event here. Its Serbian equivalent is therefore 'oživeti događaj'.

(12) It's amazing how one picture can call up an event in such detail. 'Zapanjujuće je kako jedna slika može da oživi detaljno događaj.'

Example (13) comprises two phrasal verbs: to go in, meaning 'to enter', and to go out, which has the meaning of 'to leave the building'. Their corresponding equivalents in Serbian are 'ulaziti u zgradu' and 'izlaziti iz zgrade'.

(13) An old lady spent all afternoon watching people going in and out of the building.

'Jedna stara dama provela je celo po podne gledajući ljude kako ulaze u zgradu i izlaze iz nje.’

Here are some more examples which illustrate informal English:

(14) I ran after the thief but couldn't catch him.

'Trčao sam za lopovom, ali nisam mogao da ga uhvatim.'

(15) It was somewhere at five o'clock in the afternoon when they called on me. 'Bilo je negde oko pet sati po podne kada su me posetili.'

(16) If someone criticises you unfairly, it is better to ignore them than to strike back.

'Ako te neko nepravedno kritikuje, bolje je da ga ignorišeš nego da uzvratiš napadom.' 
(17) A group of students are patiently queuing up in front of the cafeteria. 'Grupa studenata strpljivo čeka u redu ispred menze.'

(18) He could not keep up with the other students. 'Nije mogao da ide u korak sa drugim studentima.'

(19) My neighbour went to jail for having tried to bump his boss off. 'Moj komšija je dospeo u zatvor jer je pokušao da ubije svog šefa.'

Lewin and Lewin (1988) provide a long list of informal phrasal verbs meaning to kill. One of them (to bump off) is illustrated in example (19). Hlebec (2004: 24) classifies this phrasal verb as a slang, and translates it into Serbian as 'oladiti' ('ubiti').

\subsection{Some examples containing phrasal verbs in formal traffic engineering contexts}

The following examples show how phrasal verbs are employed in formal specific contexts. The phrasal verb to be fitted with sth in (20) has the meaning of 'to put a particular kind of equipment into sth such as a vehicle, room or building', and its equivalent in Serbian is 'opremiti'.

(20) It is fitted with devices which permit its easy handling.

(taken from Dimković-Telebaković 2018: 71)

'Opremljen je uređajima koji dozvoljavaju da se njim lako rukuje/upravlja.'

The meaning of the phrasal verb to run down in example (21) is 'to injure/kill sb with a car', and it occurs in written formal style. Its Serbian equivalent is 'pregaziti'. The phrasal verbs in examples (21) and (25) below demonstrate that different English phrasal verbs (to run down and to run over) can express the same meaning in different contexts.

(21) There is no implication, however, in the law that the motorist may run down the pedestrian who is crossing illegally.

(taken from Dimković-Telebaković 2015b: 5)

'U zakonu se, međutim, ne kaže da vozač motornog vozila sme da pregazi pešaka koji nepropisno prelazi pešački prelaz.'

Example (22) contains the phrasal verb to carry out, having the meaning of 'to do a particular piece of work', which is translated into Serbian as 'obaviti posao'. This example demonstrates written formal use.

(22) In Europe, much of the conceptual work for this grand plan was carried out between 1986 and 1994 as part of a program called Prometheus. 
(taken from Dimković-Telebaković 2015b: 36)

'U Evropi je dosta od onoga što je zamišljeno ovim velikim planom obavljeno između 1986. i 1994. godine kao deo programa nazvanog Prometej.'

\subsection{Neutral phrasal-verb usage}

The phrasal verb to give off, as used in (23), has the equivalent in Serbian 'ispuštati otrovne gasove'. Its use is neutral here. This means that a phrasal verb can refer to both general and specific usage, depending on a situation or type of discourse in which it is used.

(23) The machine gives off.

'Ovaj motor ispušta otrovne gasove.'

The phrasal verb to sell out has the meaning of 'to sell all', as shown by (24). Its equivalent in Serbian is 'prodati'. Examples (23), (24) and (25) demonstrate that it is not easy to draw a line between general English and specialised use in some cases, which is valid for separate sentence items in particlular.

(24) The new car make has been sold out recently.

(taken from Dimković-Telebaković 2018: 72)

'Novi model automobila je nedavno prodat.'

Example (25) contains the phrasal verb to run over. Its meaning is 'to hit someone or something with a vehicle and injure or kill them', and its Serbian equivalent is 'pregaziti'.

(25) Two persons were run over by the trolleybus two years ago.

(taken from Dimković-Telebaković 2018: 71)

'Trolejbus je pregazio dve osobe pre dve godine.'

\subsection{Phrasal verbs in dialogues and traffic engineering texts}

In this section, we shall look at phrasal verbs in three dialogues and five texts, as reflected in traffic engineering to reveal the meanings of the phrasal verbs under scrutiny, to provide their Serbian equivalents, and to establish their frequency of occurrence.

The first dialogue contains three phrasal verbs: to phone for, to look after, and to knock off. Their Serbian equivalents are 'pozvati nekoga, nešto', 'postarati se za nekoga' and 'oboriti nekoga', as shown in S. This dialogue consists of 108 words. 


\section{I}

E:

A: Has anyone phoned for an ambulance?

B: No. I think she's OK, but someone should ring for an ambulance straightaway.

C: How did it happen?

D: The car must have been going too fast.

D: She shouldn't have carried all these heavy bags on her bike.

A: The cyclist couldn't see the car coming.

B: I'm sure she didn't. I suppose she might have looked the other way.

C: Somebody ought to look after the driver. He doesn't look very well.

D: You're right. He can't feel very good after knocking that woman off her bike.

C: I feel I ought to do something instead of just standing here.

(taken from Dimković-Telebaković 2015a: 211)

S:

A: Da li je neko pozvao hitnu pomoć?

B: Ne. Mislim da je ona dobro, ali neko treba odmah da pozove hitnu pomoć.

C: Kako se to desilo?

D: Mora da su se kola kretala previše brzo.

D: Nije trebalo da nosi sve te teške torbe na biciklu.

A: Biciklistkinja nije mogla da vidi kola koja dolaze.

B: Siguran sam da nije. Pretpostavljam da je možda pogledala na drugu stranu.

C: Bilo bi potrebno da se neko postara za vozača. On ne izgleda dobro.

D: U pravu ste. On ne može da se oseća dobro nakon što je tu ženu oborio s bicikla.

C: Osećam da bi bilo potrebno da nešto uradim a ne samo da stojim ovde.

The second dialogue, having 118 words, is a telephone conversation between a passenger who is purchasing a return train ticket and Virgin trainlines employee who is selling tickets. This dialogue contains only one phrasal verb, to travel out. Its translation into Serbian is given below in parallel with the English sentence in which it occurs.

II

A: good afternoon Virgin trainlines Sandra speaking for which journey do you wish to purchase a ticket

B: it's er - Stockport erm - Watford Junction

A: Stockport to Watford Junction

B: yes please 
A: now do you hold a current debit or credit card

B: yes

A: and how many people's travelling

$\mathrm{B}$ : one

A: and what date is it you're travelling out $\quad$ 'i kog datuma biste putovali'

B: tomorrow

A: now i'm going to have to arrange for you to collect your tickets tomorrow at the train station

B: that's fine

A: so what time do you like to depart Stockport at

B: i'd like this to be processed before 2 if i could - erm - Stockport departing er er if $i$ could get a super advance return that'd be great

(taken from Dimković-Telebaković 2018: 77-78)

The third short conversation takes place on a train, where a couple is waiting for the train to leave the platform. This conversation comprises 75 words, and contains one phrasal verb, to come over $\rightarrow$ 'doći'.

\section{III}

Mr. B: Look at the time! When is this train going to leave? It's already five minutes late.

Mrs. B: Now, don't get impatient, darling. Are you sure?

Mr. B: Of course I'm sure. This is the 4.05 to London and it is now $4.10 \ldots$ no ... 4.11 .

Mrs. B: Well don't get angry with me, darling. Look at that guard on the platform. Tell him.

Mr. B: A very good idea! (opening window and shouting) Guard! Guard! Come over here, please.

'Molim Vas dođite ovde.' (adapted from R. O'Neill 1975)

In order to reveal how frequently phrasal verbs emerge in written traffic engineering discourse, we have analysed five texts taken from a textbook English in Transport and Traffic Engineering (Dimković-Telebaković 2015a).

The first text in the book, (from a British journal Transport), refers to combined traffic field, is composed of 544 words, and has no phrasal verbs.

A text on 'Some basic features of satellite communications', taken from an American handbook, comprises 419 words and incorporates three phrasal verbs. They are as follows: to consist of $\rightarrow$ 'sastojati se od', to depend on $\rightarrow$ 'zavisiti od', and to send back $\rightarrow$ 'vratiti'. 
(26) Throughout history the communication task has consisted of two problems. 'Zadatak komunikacije se tokom istorije sastojao od dva problema.'

(27) Satellite systems depend heavily on technology, including rocketry, space mechanics, solid-state electronics, high-frequency electronics and radiation, and modern communications networks.

'Satelitski sistemi pretežno zavise od tehnike, uključujući raketnu tehniku, kosmičku mehaniku, poluprovodničku elektroniku, elektroniku visokih učestalosti i emitovanje signala, i savremene komunikacione mreže.'

(28) It has one or more antennas which receive radiation from the earth and send radiation back to the earth.

'Ima jednu ili više antena koje primaju signale sa Zemlje i šalju signale nazad na Zemlju.'

The third analysed text, entitled 'How an aircraft is controlled?', is taken from Encyclopedia Britannica International, and has five phrasal verbs: to go up $\rightarrow$ 'kretati se ka gore', to go down $\rightarrow$ 'kretati se ka dole', to push on $\rightarrow$ 'gurati', to pull on $\rightarrow$ 'vući', and to slow down $\rightarrow$ 'usporiti'. This text contains 522 words.

(29) The ailerons are hinged to the wings and are connected so that they move in opposite directions; one goes up when the other goes down.

'Krilca aviona su pričvršćena šarkama za krila i povezana tako da se kreću u suprotnom smeru; jedno krilce se kreće ka gore kada se drugo krilce kreće ka dole.'

(30) When the pilot pushes on the right rudder pedal, he will see the aircraft's nose move to the right.

'Kada pilot gura desnu pedalu za upravljanje vertikalnim kormilom, videće da se nos vazduhoplova kreće udesno.'

(31) The pilot uses this to adjust the fore and aft balance of the aircraft, so that he does not have to push or pull on the control column all the time he is flying.

'Pilot ovo koristi da podesi uzdužnu ravnotežu vazduhoplova, tako da ne mora da gura ili vuče polugu za upravljanje avionom sve vreme dok leti.'

(32) Aircraft usually need brakes on their wheels to slow them down after landing and to help the pilot steer when he is taxiing on the ground.

'Vazduhoplovima su obično potrebne kočnice na točkovima da bi ih usporili nakon sletanja i da bi pomogle pilotu da usmerava avion kada se kreće po zemlji.' 
Four phrasal verbs are found in a text, having 763 words. It is on 'Traffic Safety Specific Factors', taken from a monograph, and the phrasal verbs contained in it are as follows: to be connected to sth $\rightarrow$ 'biti povezan s nečim', to associate sth with sth $\rightarrow$ 'dovesti nešto u vezu s nečim', to attribute sth to sth $\rightarrow$ 'pripisivati nešto nečemu', and to focus on $\rightarrow$ 'usredsrediti se na nešto', 'obratiti posebnu pažnju na nešto/na nekog'.

(33) ... every aspect of the traffic system is in some way connected to every other aspect.

'... svaki vid saobraćajnog sistema je na neki način povezan sa svim drugim vidovima saobraćajnog sistema.'

(34) ... but also different speed limits, driver speed choices, and driver vigilance levels are associated with different types of roadways.

'... ali takođe se različita ograničenja brzine, vozačev izbor brzine i nivoi budnosti vozača dovode u vezu s različitim tipovima kolovoza.'

(35) The pitfalls of examining simple rates and attributing the differences to engineering factors are further illustrated using insurance data.

'Problemi pri ispitivanju jednostavnih slučajeva i pri pripisivanju teškoća inženjerskim faktorima dalje su prikazani uz korišćenje podataka o osiguranju.'

(36) Focusing on station wagons shows a $31 \%$ higher rate for midsized compared to large, and a $71 \%$ higher rate for small compared to large.

Usredsređenost $n a$ automobile-karavane pokazuje da su veliki karavani bezbedniji $31 \%$ od karavana srednje veličine, dok su veliki karavani bezbedniji $71 \%$ od malih karavana.

The longest text, which is about Electronic Data Interchange (EDI), comprises 974 words, but incorporates only three phrasal verbs: to be derived from sth $\rightarrow$ 'izvoditi se iz, poticati iz/od nečega', to hand over $\rightarrow$ 'prenositi se', and to stand for $\rightarrow$ 'predstaviti'. This text is taken from Postal Techology.

(37) All four EDIFACT messages are derived from a logical data model which contain the definitions of the data being exchanged.

'Sve četiri EDIFACT poruke izvode se iz modela logičkih podataka koji sadrže određenje podataka koji se razmenjuju.'

(38) PRECON or 'Preadvice of receptacles handed over' contains information about a consignment of mail once it has been prepared for handover to a carrier, usually an airline.

'PREKON ili "Obaveštenje o poštanskim kontejnerima koji se prenose" sadrži informaciju o isporuci pošte spremne za prenos do prevoznika, obično aviokompanije.' 
(39) RESCON stands for 'Confirmation of consignment receipt or current expectations.'

'RESCON predstavlja "Potvrdu o prijemu isporuke ili sadašnjem stanju”.'

Table 1 shows the number of words of which the three dialogues and five texts are made up, and the number of phrasal verbs contained in them. It also presents the phrasal verb frequency of occurrence in the dialogues and written traffic engineering texts analysed. There is conclusive evidence that dialogues have a higher phrasal verb frequency than traffic engineering texts, since the quantitive estimate for the dialogues is $1.66 \%$ and for the texts $0.46 \%$. This result that phrasal verbs are more commonly used in conversation than in traffic engineering texts is in accordance with Biber et al.'s finding (see Biber et al. 1999: 403-428), where they examine phrasal verbs in conversation and academic writing (which is a kind of written specialised language).

\begin{tabular}{|c|c|c|c|}
\hline \multicolumn{4}{|c|}{ Dialogues } \\
\hline \multicolumn{2}{|c|}{ Word number } & Phrasal verb number & Percentage \\
\hline I & 108 & 3 & \\
\hline II & 118 & 1 & \\
\hline & 75 & 1 & \\
\hline \multicolumn{2}{|c|}{ Total: 301} & 5 & $1.66 \%$ \\
\hline \multicolumn{4}{|c|}{ Texts } \\
\hline \multicolumn{2}{|c|}{ Word number } & Phrasal verb number & Percentage \\
\hline & 544 & 0 & \\
\hline & 419 & 3 & \\
\hline & 522 & 5 & \\
\hline & 763 & 4 & \\
\hline & 974 & 3 & \\
\hline & 222 & 15 & $0.46 \%$ \\
\hline
\end{tabular}

Table 1. Phrasal verbs in dialogues and traffic engineering texts

\section{Concluding remarks}

Some findings of this study confirm the hypothesis that phrasal verbs are frequently used in spoken English and to a lesser degree in written traffic engineering English (the ratio being approximately 3 to 1 ). As the texts chosen for our investigation 
are taken from British and American journals, a handbook, an encyclopedia and a monograph, it is possible to conclude that English specialised traffic engineering texts of different genre type contain phrasal verbs. Examples in this paper also provide evidence for informal, formal and neutral use of phrasal verbs.

A number of examples in the analysis reveal that polysemy is one characteristic of phrasal verbs if used in various settings (e. g. to roll out, to take off, to back up, etc.). Contrary to this, some other examples show that different phrasal verbs can have the same meaning when used in informal English (e. g. to drop off, to go off, or to gronk out $\rightarrow$ 'zaspati'). This diversity makes phraseology a worthy field of study as far as contrastive analysis is concerned, and it is also of importance for the foreign language learning and teaching.

As for the Serbian equivalents of the English phrasal verbs discussed here, one can notice that they are normally monolexemes if phrasal units are made up of two components (e. g. to call on $\rightarrow$ 'posetiti', to run over $\rightarrow$ 'pregaziti', etc.), although they also end up in more words in Serbian, such as in 'ispuštati otrovne gasove' $\rightarrow$ to give off, 'usredsrediti se na nešto', 'obratiti posebnu pažnju na nešto/na nekog' $\rightarrow$ to focus on. Phrasal verbs, comprising three elements, normally have more constituents in Serbian equivalents (e. g. to keep up with $\rightarrow$ 'ići u korak sa', to get through to sth $\rightarrow$ 'uspostaviti vezu sa nekim, s nečim', etc.), but convey one meaning. The fact that the meaning of a phrasal verb is deduced from the phraseological unit as a whole reveals the second characteristic of phrasal verbs - idiomaticity or non-compositionality.

\section{References}

Alexander, R. (1978). Fixed expressions in English: A linguistic, psycholinguistic, sociolinguistic and didactic study (part 1). Anglistik und Englischunterricht, 6, 171-188.

Biber, D. et al. (1999). Longman Grammar of Spoken and Written English. Harlow: Longman.

Cowie, A. P. (1994). Phraseology. In: R. E. Asher (ed.), The Encyclopedia of Language and Linguistics, Oxford: Pergamon Press, 3168-3171.

Dimković-Telebaković, G. (2013). On English Phrasal Verbs and Their Single-Word Equivalents. In: I. Lakić and N. Kostić (eds.), Conference Proceedings Across Languages and Cultures, Podgorica: University of Montenegro, Institute of Foreign Languages, 91-96.

Hlebec, B. (2004). Englesko-srpski, srpsko-engleski rečnik slenga. Beograd: Beogradska knjiga. 
Howarth, P. (1998). Phraseology and Second Language Proficiency. Applied Linguistics, 19(1), 24-44.

Jackendoff, R. (2002). English particle constructions, the lexicon and the autonomy of syntax. In: N. Dehé et al. (eds.), Verb-particle explorations, Berlin: Mouton de Gruyter, 67-94.

Lakoff, G. (1973). Hedges: A study in meaning criteria and the logic of fuzzy concepts. Journal of Philosophical Logic, 2, 458-508.

Lewin, E. and A. E. Lewin (1988). The Random Thesaurus of Slang. New York: Random House.

Lipka, L. (1972). Semantic structure and word formation. Verb-particle constructions in contemporary English. München: Fink.

Maxwell, K. (2005). New word of the month. MED Magazine, 29. (26 June 2019) $<$ http://www.macmillandictionaries.com/MED-Magazine/April2005/29-NewWord-Gronk-Out-print.htm>.

Mitchell, T. F. (1958). Syntagmatic Relations in Linguistic Analysis. Transactions of the Philological Society, 57(1), 101-118.

Palmer, F. R. (1988). The English Verb. $2^{\text {nd }}$ edition. London and New York: Longman.

\section{Sources}

Dimković-Telebaković, G. (2015a). English in Transport and Traffic Engineering. VI izdanje. Beograd: Univerzitet u Beogradu, Saobraćajni fakultet.

Dimković-Telebaković, G. (2015b). Testovi, zadaci i teme iz engleskog jezika. VI izdanje. Beograd: Univerzitet u Beogradu, Saobraćajni fakultet.

Dimković-Telebaković, G. (2018). English Grammar for transport and traffic engineers. Beograd: Univerzitet u Beogradu, Saobraćajni fakultet.

McCarthy, M. and F. O'Dell (2007). English Phrasal Verbs in Use. Cambridge: Cambridge University Press.

O'Neill, R. (1975). English in Situations. $6^{\text {th }}$ edition. Oxford: Oxford University Press. Rundell, M. (ed.) (2005). Macmillan Phrasal Verbs Plus. Oxford: Bloomsbury Publishing Plc and A\&C Black Publishers Ltd. 